\section{Response to "To switch or not to switch': the missing piece in the puzzle of biosimilar literature?' by Scherlinger et al}

Thank you for the interest ${ }^{1}$ in our recent publication, in which we explored treatment outcomes following a Danish mandatory switch from originator to biosimilar etanercept (SB4, $50 \mathrm{mg}$ ) in routine care. ${ }^{2}$ We showed that of the 2061 patients who were receiving originator etanercept and thus were eligible for the switch, as many as four of five (79\%) switched to the biosimilar, despite the continued availability of the originator drug (as $25 \mathrm{mg}$ pen or $50 \mathrm{mg}$ powder solution). Among the patients who switched, we observed high retention rates of the biosimilar. The 6-month retention rate after switch (88\%) was very similar to results of a recent Dutch study (90\%), which reported outcomes of a non-mandatory switch following a specifically designed communication strategy. ${ }^{3}$ Furthermore, we found that the disease activity and flare rates 3 months prior to versus 3 months after the switch were similar at the level of the individual patients. Thus, we agree with Scherlinger and Schaeverbeke that biosimilars hold the potential to provide sustainable healthcare in inflammatory rheumatic diseases at reduced costs. ${ }^{1}$

The question raised by Scherlinger et al is whether the outcome of a shared patient-physician decision (=non-mandatory) is more favourable than a mandatory switch. In previous studies that explored non-mandatory switching, the shared patientphysician decision-making included training of personnel and use of specific questionnaires or communication techniques. ${ }^{34}$ For the Danish mandatory switch, no extra resources were allocated to conduct the switch procedure and no specific education of the healthcare personnel was provided. Furthermore, it was beyond the scope of our study to explore the practical aspects of the switch procedure including communication strategy with the patients. However, we have previously demonstrated that a mandatory switch from originator to biosimilar infliximab did not lead to a detectable increase in the use of healthcare resources. ${ }^{5}$

To determine whether shared patient-physician decision is superior to a mandatory switch in terms of lower nocebo effect, increased treatment efficacy and reduced healthcare costs, large-scale studies which are designed to explore these specific aspects are necessary—and highly needed. Such studies must also include evaluation of the extra healthcare resources allocated to and arising from the strategies investigated.

In conclusion, our paper adds important evidence to the use of biosimilars in routine care-however, some pieces are still missing in the puzzle.

\footnotetext{
Bente Glintborg $\odot$, 1,2 Anne Gitte Loft, ${ }^{3,4}$ Emina Omerovic, ${ }^{5}$ Oliver Hendricks, ${ }^{6}$ Asta Linauskas, ${ }^{7}$ Jakob Espesen, ${ }^{8}$ Kamilla Danebod, ${ }^{2}$ Dorte Vendelbo Jensen, ${ }^{2}$ Henrik Nordin, ${ }^{9}$ Emil Barner Dalgaard, ${ }^{10}$ Stavros Chrysidis, ${ }^{11}$ Salome Kristensen, ${ }^{12}$ Johnny Lillelund Raun, ${ }^{13}$ Hanne Lindegaard, ${ }^{14}$ Natalia Manilo, ${ }^{15}$ Susanne Højmark Jakobsen, ${ }^{16}$ Inger Marie Jensen Hansen, ${ }^{16}$ Dorte Dalsgaard Pedersen, ${ }^{17}$ Inge Juul Sørensen, ${ }^{1,18}$ Lis Smedegaard Andersen, ${ }^{19}$ Jolanta Grydehøj, ${ }^{20}$ Frank Mehnert, ${ }^{21}$ Niels Steen Krogh, ${ }^{22}$ Merete Lund Hetland ${ }^{18}$

${ }^{1}$ The DANBIO Registry and Copenhagen Center for Arthritis Research (COPECARE), Center for Rheumatology and Spine Diseases, Centre of Head and Orthopaedics, Glostrup, Denmark

2Department of Rheumatology, Gentofte and Herlev Hospital, Copenhagen University Hospital, Gentofte, Denmark

${ }^{3}$ Department of Rheumatology, Aarhus University Hospital, Aarhus, Denmark

${ }^{4}$ Department of Clinical Medicine, Aarhus University, Aarhus, Denmark
}

${ }^{5}$ Department of Rheumatology, Center for Rheumatology and Spine Diseases, Centre of Head and Orthopaedics, Rigshospitalet, Copenhagen University Hospital, Glostrup, Denmark

${ }^{6}$ Kong Christian X's Gigthospital, Gråsten, Denmark

${ }^{7}$ Department of Rheumatology, North Denmark Regional Hospital, Hjørring, Denmark ${ }^{8}$ Department of Rheumatology, Vejle Hospital, Vejle, Denmark

${ }^{9}$ Department of Rheumatology, Zealand University Hospital, Køge, Denmark

${ }^{10}$ Department of Rheumatology, Silkeborg Hospital, Silkeborg, Denmark

${ }^{11}$ Department of Rheumatology, Esbjerg Hospital, Esbjerg, Denmark

${ }^{12}$ Department of Rheumatology, Aalborg University Hospital, Aalborg, Denmark

${ }^{13}$ Department of Rheumatology, Sygehus Lillebælt, Kolding, Denmark

${ }^{14}$ Department of Rheumatology, Odense University Hospital, Odense, Denmark

${ }^{15}$ Department of Rheumatology, Frederiksberg Hospital, Copenhagen, Denmark

${ }^{16}$ Department of Rheumatology, OUH, Svendborg Hospital, Svendborg, Denmark

${ }^{17}$ Department of Rheumatology, Viborg Hospital, Viborg, Denmark

${ }^{18}$ Department of Clinical Medicine, Faculty of Health and Medical Sciences, University of Copenhagen, Copenhagen, Denmark

${ }^{19}$ Department of Internal Medicine, Rønne Hospital, Rønne, Denmark

${ }^{20}$ Department of Rheumatology, Holstebro Hospital, Holstebro, Denmark

${ }^{21}$ Department of Clinical Epidemiology, Aarhus University Hospital, Aarhus, Denmark

${ }^{22}$ ZiteLab, Copenhagen, Denmark

Correspondence to Dr Bente Glintborg, The DANBIO Registry, Rigshospitalet, and Department of Rheumatology, Gentofte and Herlev University Hospital, Glostrup 2600, Denmark; glintborg@dadlnet.dk

Handling editor Josef S Smolen

Contributors All authors contributed to and approved this letter to the editor.

Funding The authors have not declared a specific grant for this research from any funding agency in the public, commercial or not-for-profit sectors.

Competing interests BG: AbbVie, Biogen, Pfizer, MSD. MLH: Orion, BMS, AbbVie, Biogen, Pfizer, MSD, Celltrion. IMJH: Roche. AGL: AbbVie, MSD, Novartis, Pfizer, Roche, UCB. OH: AbbVie, Roche, Novartis. HN: AbbVie, Novartis, Medac. LSA Pfizer.

Patient consent for publication Not required.

Provenance and peer review Commissioned; internally peer reviewed. (c) Author(s) (or their employer(s)) 2020. No commercial re-use. See rights and permissions. Published by BMJ.

\section{Check for updates}

To cite Glintborg B, Loft AG, Omerovic E, et al. Ann Rheum Dis 2020;79:e37.

Received 2 January 2019

Accepted 2 January 2019

Published Online First 23 January 2019

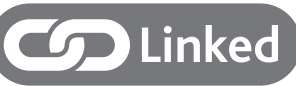

- https://doi.org/10.1136/annrheumdis-2018-214908

Ann Rheum Dis 2020;79:e37. doi:10.1136/annrheumdis-2018-214952

ORCID iD

Bente Glintborg http://orcid.org/0000-0002-8931-8482

\section{REFERENCES}

1 Scherlinger M, Schaeverbeke T. 'To switch or not to switch': the missing piece in the puzzle of biosimilar literature? Ann Rheum Dis 2020;79:e36.

2 Glintborg B, Loft AG, Omerovic E, et al. To switch or not to switch: results of a nationwide guideline of mandatory switching from originator to biosimilar etanercept. one-year treatment outcomes in 2061 patients with inflammatory arthritis from the DANBIO registry. Ann Rheum Dis 2019;78:192-200.

3 Tweehuysen L, Huiskes VJB, van den Bemt BJF, et al. Open-label, non-mandatory transitioning from originator etanercept to Biosimilar Sb4: six-month results from a controlled cohort study. Arthritis Rheumatol 2018;70:1408-18.

4 Scherlinger M, Langlois E, Germain V, et al. Acceptance rate and sociological factors involved in the switch from originator to biosimilar etanercept (Sb4). Semin Arthritis Rheum 2018

5 Glintborg B, Sørensen J, Hetland ML. Does a mandatory non-medical switch from originator to biosimilar infliximab lead to increased use of outpatient healthcare resources? A register-based study in patients with inflammatory arthritis. RMD Open 2018;4:e000710. 